\title{
Embodied Tree: Empowering Its Symbolic Strength Through Creative Arts Therapy
}

\author{
具身化的树：通过创造性艺术治疗赋予树象征性力量 \\ Mimma Della Cagnoletta, Rosa Maria Govoni and \\ Donatella Mondino \\ Art Therapy Italiana Association, Bologna, Italy
}

\begin{abstract}
When fear and anxiety for the future gain ground inside of us, nature helps to restore our inner balance and strengthen our link to life. In a webinar for creative arts therapists, we used movements and art to connect with the wisdom of the tree. We embodied its symbolic power, which subsequently represented it in an art form. The tree's resemblance to the human body and its use as a symbol in myths made it a vehicle to regain a sense of life's continuation and transformation. As trees are interconnected through their roots, participants co-constructed a unity and a continuity with each other, a precious feeling in a time of isolation and absence of contact.
\end{abstract}

Keywords: creative process, art and movement, interconnection, embodied tree, transformation

\section{摘要}

当对未来的恐惧和焦虑在我们内心占据主导地位时，大自然有助于恢复内心的平衡，加 强我们与生命的联结。在一次为创造性艺术治疗师举办的网络研讨会上，我们用动作和 艺术与树的智慧连接。我们具身化了树的象征性力量，随后以一种艺术形式呈现出来。 树与人体有相似性，它在神话中作为一种象征使用，这使它成为重获生命延续感和转化 的载体。由于树木通过它们的根部相互连接，参与者在彼此之间共建了一种整体性与联 结感，在一个孤立和缺之联系的时代，这是一种珍贵的感觉。

关键词: 创作过程，艺术和动作，相互连接，具身化的树，转化

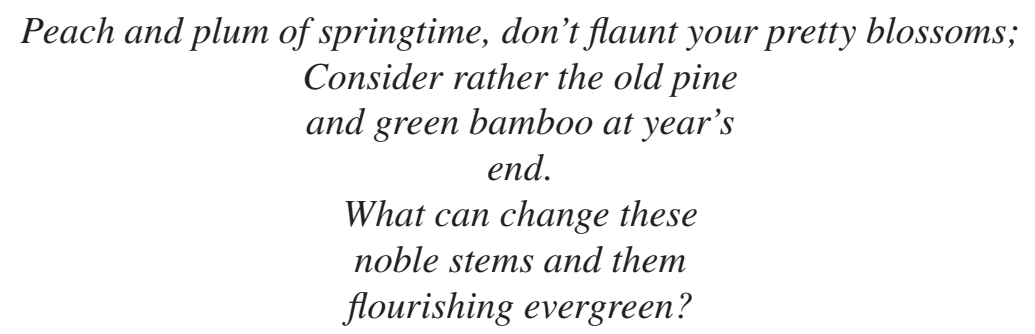

Kim Yuki (1580-1658) 
Nature is a comfort and a companion for many people, but during the pandemic, biophilia, the love for nature, became essential for well-being. In absence of human presence and contact, walking in the park and wandering in the woods was a way of keeping memory of the flow of energy emanating from the trees and reaching us in a healing cycle.

For those of us confined in a small apartment, even a plant growing and flowering inside a pot supplied us with a change in time, while everything else seemed timeless and uncertain. Nature, even in the form of a house plant, went through phases of transformation and reminded us of our "going on being" (Winnicott, 1971).

In a webinar that took place during the height of the lockdown in Italy, when even walking outside of the house was forbidden, the authors have employed movements, art works, and imagination in order to create the same enlivened connection with trees that we experience while walking in the woods (Figure 1).

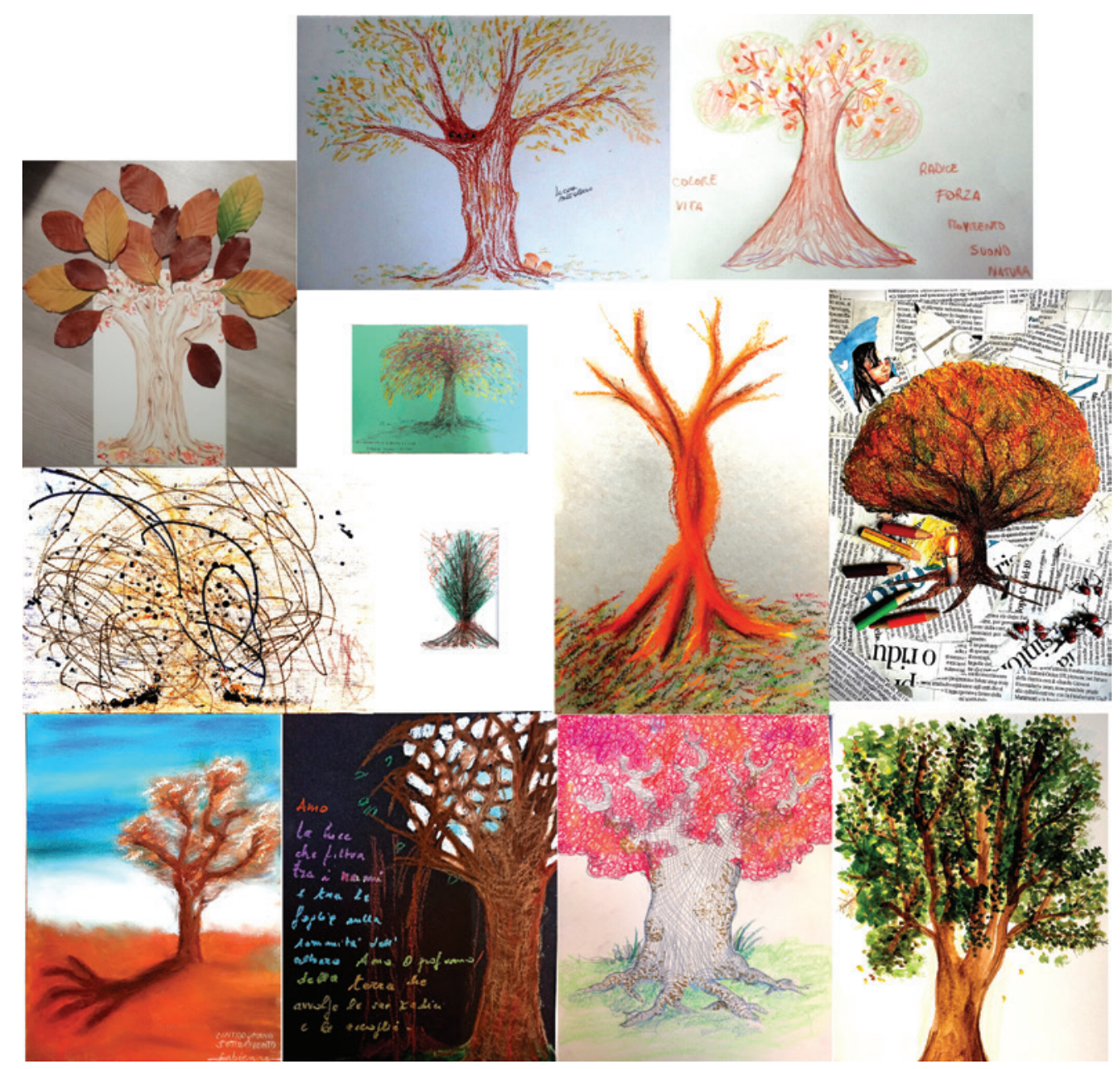

FIGURE 1 | Some of the trees depicted by webinar's participants. 
Imagination is rooted in bodily perceptions and feelings (Milner, 1987; Winnicott, 1988), it sustains affects and words while giving meaning to inner and outer events. By using the symbol of the tree, we aimed to generate a common language with the colleagues attending the webinar and form a profound network capable of providing good enough nourishment in time of deprivation.

Oliver Sacks (2019) remarked on the intensity of the bodily effect of gardens and woods on humans and considered the deep changes on the brain's physiology and perhaps even on its structure. He used to take his patients to gardens in order to improve their physiological states and suggested that these visits were necessary for individual and community wellbeing.

The ability of the tree to grow, blossom, and bear fruits, to renew itself through the cycle of loss and stasis, traces the path for humans, who learn from the tree how to expand, to offer its beauty and its potential, to perpetuate life through the ability to generate and create, to go through loss, mourning, and immobility, and to be finally transformed (Figure 2).

Although many cultures celebrate the symbolic aspects of the tree, with its capacity of facing difficulties and hard times, by swinging and adapting to strenuous conditions and situations, others celebrate the Latin motto "Frangar non flectar" "'I break but I do not bend"), which conveys a totally different approach to life events. The Latin motto acknowledges domination and separateness, with an omnipotent vision of a verticality that never gives up, whereas the other, more directly connected with nature and its wisdom, knows how to yield and surrender to preserve life.

\section{Resources, Body, and Nature}

"Dance movement" is, according to Halprin (1997), imagination and creativity in motion. The process of searching for a creative source begins with the experience of perceiving one's own body and listening to our movements. Working with the body and its movements offers some relief in the here and now, whatever circumstances we are in, even on line, as experienced in the International Association for Creative Arts in Education and Therapy webinar led by Helen Payne (January 2021).

Promoting an embodied presence in a period of great uncertainty implies providing experiences capable of restoring a sense of unity and security in ourselves (Porges, 2011). A deep way to reintegrate and feel connected to good energy, vitality, and consolation comes with the feeling of interrelation with nature: "We are all part of a bigger Body, and the bigger Body is Nature herself. ... our focus is to heighten our awareness of the natural world and to experience how this awareness can support our healing" (Halprin, 1997, p. 105) (Figure 3).

When we are confined at home, the "awareness of the natural world "can be summoned up through our imagination. Moving and being moved by an image revitalize resources within our own selves. Affects, images, and words can flow and circulate again in a potential space, the imagination realm, a dimension that is not outside, nor inside, but in between (Winnicott, 1971). 


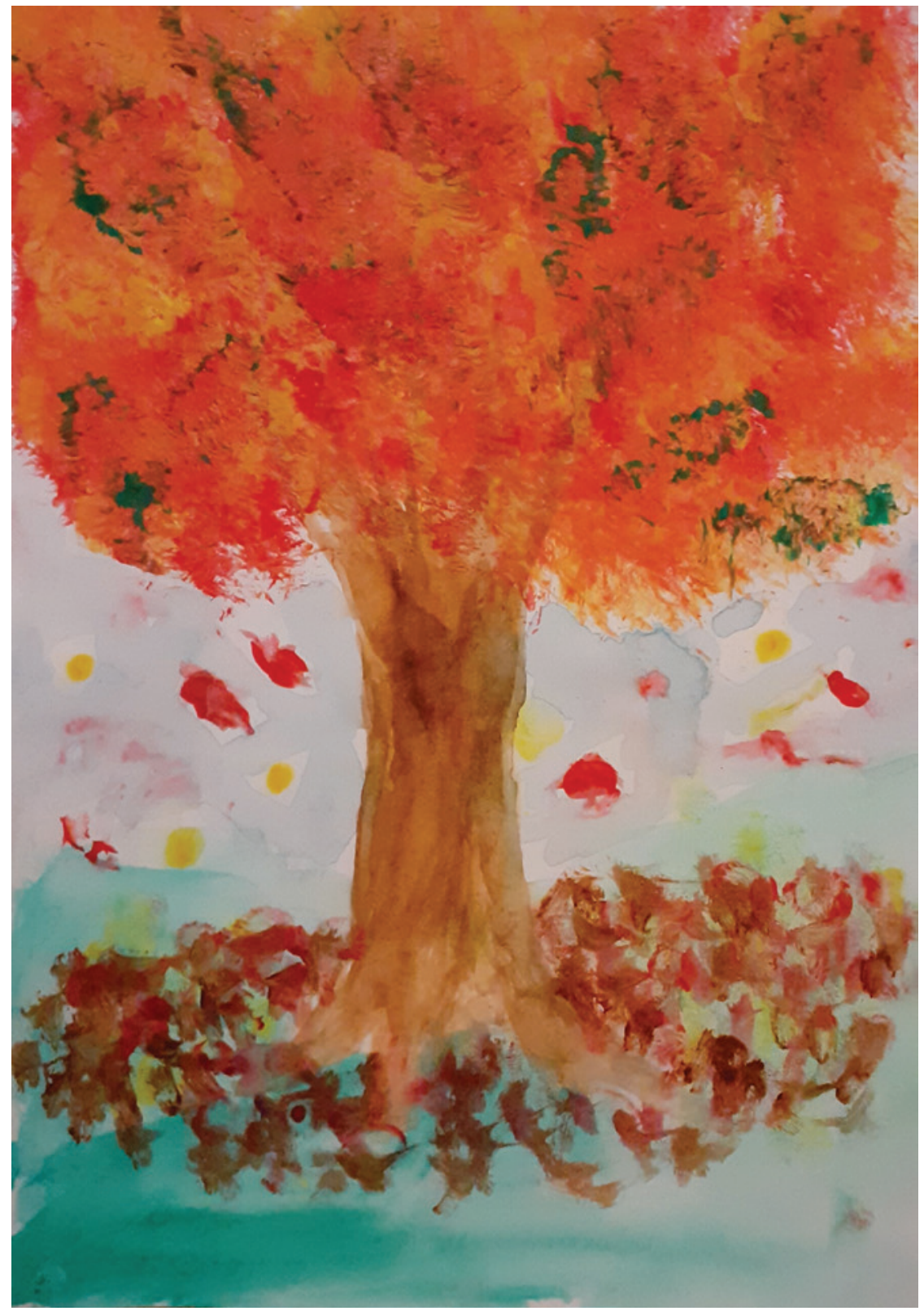

FIGURE 2 | Life cycle.

Laban (1960), Bartenieff (1980), and Kestenberg et al. (1999) helped us discern the qualitative aspects of movements, based on different gradients of body energy, distributed and regulated in all body parts by the flow of movements. Following their principles, we can perceive our own body and listen to our movements, in order to promote ways for restoring basic safety states (Gray, 2017). 


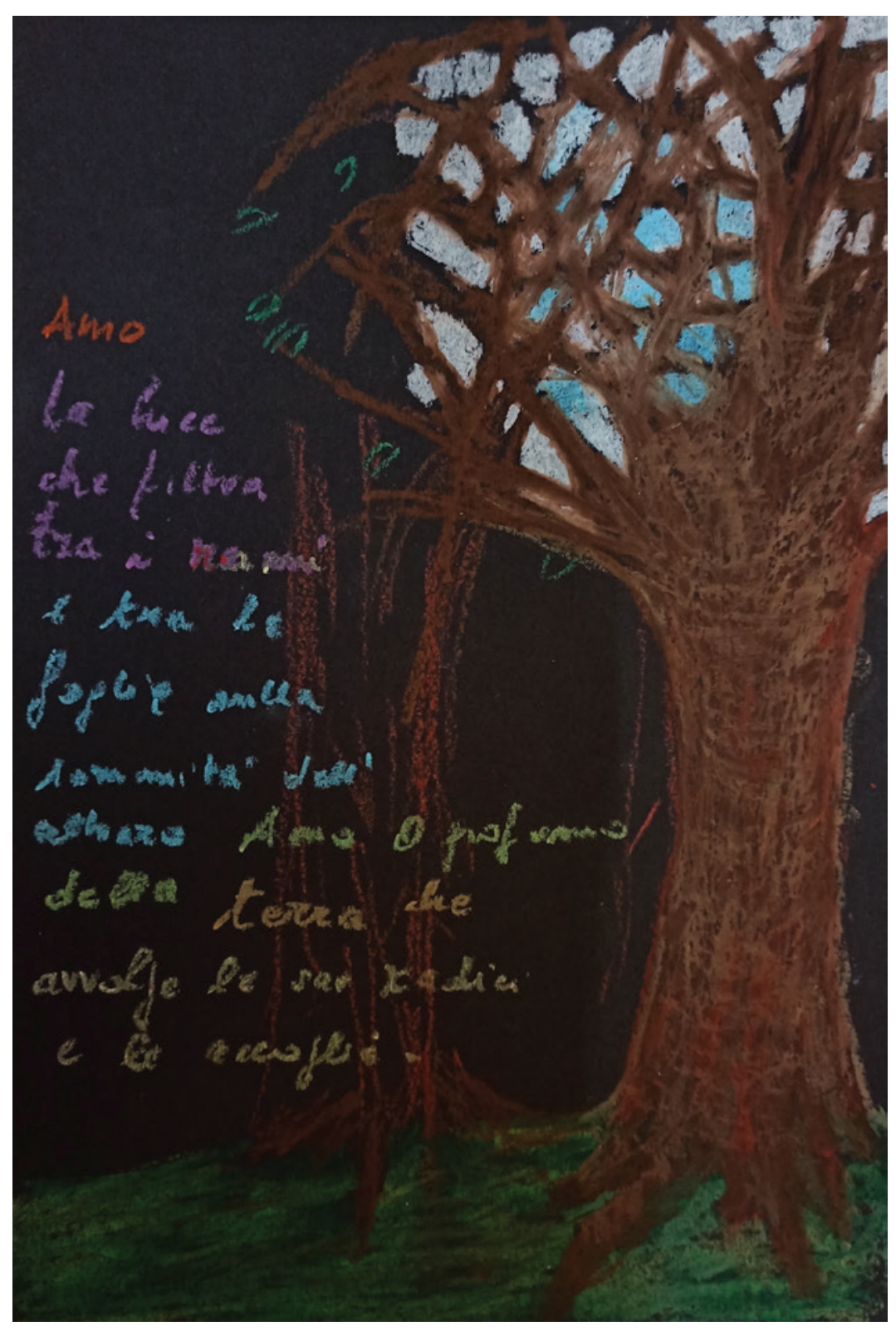

FIGURE 3 | "Amo" (What I love).

Self-regulation processes (Ogden, Minton, \& Pain, 2006) consist of focusing on body awareness, on breathing, on sensing our body weight, on grounding, on perceiving our kinesphere and our personal space, on feeling the expansion of the space itself, the qualities of movements, their energy, and their colors.

"The use of imagination, combined with kinesthetic intelligence, which includes the ability to keep one's balance, to clarify boundaries, to read the messages from one's 
body" (Serlin, 2020, p. 178), is effective in recovering a sense of greater well-being and in generating a more reassuring, beneficial and creative contact with ourselves (Payne, 2021). It is a way to "re-inhabit" our body, as a place of precious resources.

These processes are more valuable and rewarding when our internal witness (Adler, 1999) is present as it happens during the practice of Authentic Movement. Our internal witness must be active with her/his benevolent, loving, and compassionate attitude. Her/his task is to generate consciousness, tracking our body movements, sensations, and emotions. With her/his help, we can find useful instruments in our body to face uncertainty, pain, discomfort, separations, and anxiety-all the difficulties we are globally experiencing at present.

\section{Embodying the Tree}

A tree has a trunk, like the trunk of our body, it has limbs as we do, it has directions, upwards and downwards, front and back, left side and right side like a human, allowing an intuitive identification with it (Figure 4). By feeling connected with a tree, we can symbolically relate to Mother Earth and Father Sky (Hillman, 1997) and form a bridge between different polarities (Govoni \& Weatherhogg, 2007).

"Polarity is present in the physical body ... no actions can be accomplished without the operation of two set of muscles, one contracting one extending. ... polarity is present in the pattern of movement ... closed/open, narrow/wide, up/down, heavy/ light" (Whitehouse, 1979, p. 55). Polarity is present in the profound experience of every creative arts therapist as recalled by Stromsted (1998):"Dance has taught me to experience myself and others trough movement but I needed to embrace stillness. ... Joan Chodorow introduced me to Authentic Movement which brought both worlds together, allowing me to explore inner and outer life along the spectrum from stillness to movement" (p. 148).

A tree is still yet it can move with the wind and contains movements inside, internal unseen movements such as the ones created by chlorophyll synthesis processes and the ones going on underneath the ground, where the roots communicate and exchange. As Plevin (2007) says, talking about human beings, "The smallest micro-parts of us are always in motion, even if we are physically still" (p. 359).

\section{Practical Experience}

In the webinar "Movement and Traces, Resources for Creative Art Therapists in a Time of Crisis," we guided participants through a series of body and art experiences, in search of their inner image of a tree.

The steps of their journey included the following:

1. Finding a safe space: making your "personal place" protected and intimate, by placing yourself, yielding and discovering holding and support, paying attention to your sensations and breathing patterns, in a calming meditative way. This first phase aims to promote a sense of self-integrity (Bartenieff, 1980; Gray, 2017). 


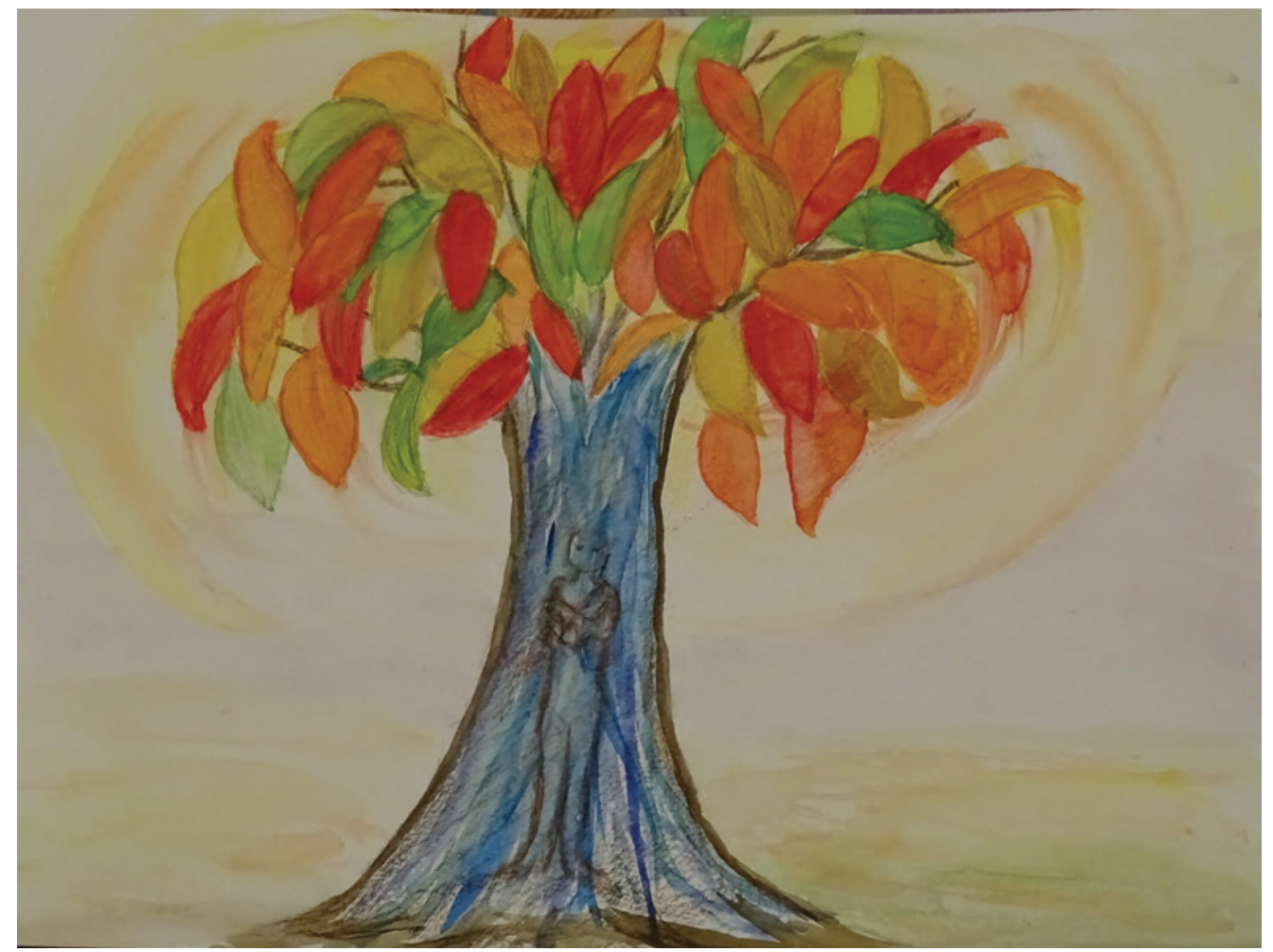

FIGURE 4 | My self-tree.

2. Reaching a standing position: being aware of this kinesthetic passage, implied in the change of level, so important in human development, feeling the inner connection between the pelvis and the feet, finding your grounding, through movement flow from feet to head. This second phase aims to foster vertical presence and empower physical and emotional presence (Laban, 1960; Kestenberg et al., 1999)

3. Promoting image formation by using an imaginative sensory warmup: while your feet touch the ground, imagine to send down your roots and receive from the earth vital nurturing lymph and imagine your upper part of the body connecting with the air and the sky, and finally, stretch and expand the movements of the limbs in space, like tree branches that reach out and widen. This third phase aims to consider the polarities in body sensations and dynamics between up and down, sky and earth, and identify opposite forces and impulses, creating a connection from body sensing and feeling to imagery processes (Bernstein, 1979; Whitehouse, 1979; Halprin, 1997; Serlin, 2020).

In the guided imagery, we entered the woods, searching for a tree to make physical contact with, evoking sensations, visions, sounds, practicing the awareness of body 
perceptions, images, emotions and thoughts, at the presence of our inner witness. Once a relationship with the tree was felt, a union of body-perception-image was born from bodily experience. This process started from the body and ended when the image became alive and vibrant. The depicted tree that was created at the end resulted in being a companion, a hidden mysterious friend, a shelter, a benevolent witness.

\section{Painting a Tree}

Milner (1987) narrates that John Ruskin, an English art critic and artist from the Victorian era, on his trip to Italy, felt so sick that he thought he might die. He went for a walk, but he had to sit down. In a state of despair, his attention was caught by an aspen tree and he started to draw it. By the time the tree was fully reproduced, he felt much better and he was capable of resuming his journey.

In quoting this episode, Stokes (Milner, ibid.), relying on classical psychoanalytic tradition, talks of a "life-enhancing effect," based on the tree as a symbol and coming from the incorporation of a good object.

Another way of understanding the improvement of Ruskin's health comes from Milner's considerations about what happens when copying an outside object. She describes from her personal experience, "a change in one's whole body perception" (Milner, ibid., p. 237), which comes from a direct (and therefore not mediated by symbols) recognition of the object that creates an internal body awareness. She uses the term "concentration of the body" to describe "certain phenomena to do with one's way of attending to the object one is painting "(Milner, ibid., p. 239). This concentration is acquired when the focus of our attention creates a flux of energy that flows from the object to our body and vice versa.

The quality of this concentration is the same with what we experience in meditation as well as in the practice of mindfulness.

Bodily concentration (Della Cagnoletta, 2010) is one of the three modalities of the creative process, which relies on sensory perception. This mode of apperception is the first we acquire, but it remains active throughout our lives even if it could be unconsidered, underused, or split. Our experiences are formed by various sources, sensory data, and inner worlds (Damasio, 2018) coming together to create images and map the world. In the creative process, body sensations emerging from the use of art materials, esthetic considerations based on our own personal history, and inner images conjoin to narrate our view of the world.

As Milner (ibid.) said, everybody's experiences are "inextricably bound up with the inner images of the relations with another person - the good incorporated objectsince the force that created our bodies and go on doing so, couldn't have kept us alive as infants without the devoted care of another person" (p. 237). During our life, we have learned that the source of comfort must be "created and go on creating" inside of us. This process is not carried through in isolation, but on the contrary, it gets its strength through the relationship with other beings.

In our webinar, in the absence of physical contact, we used the image of the tree as a source of comfort. Is the tree outside of us? Is it inside? Or is it in between? 
The process of imagination created a bridge between the two dimensions, and the experience achieved a transitional quality, which has the function of reconciling the feeling of being alone, in front of a screen, with the need of being in the company of the other.

The group achieved a sense of shared life, and the pictures of the trees, showed and commented upon by participants at the end of the workshop, provided connection, mirror, and empathy. The recognition of common symbols formed a social communal ground that fought against isolation and loneliness, just like a copse in the woods, cooperating for their common life within their hidden network.

\section{Personal Thoughts and Images}

Rosa Maria Govoni: In the days that followed the webinar, I met, walking in the woods, the tree "with eyes." I felt that this tree was a "witness" of what happens around, of the continuity of time. I thought of the benevolent eyes of the "silent witness" (Adler, 2002). A delicate, tender but tenacious, firm, resistant and constant presence. Her/his attentive, sensitive, and interested gaze accompanies us inside and outside. In front of this tree, I concentrate on my body and feel my presence, grounding in connection to the earth. My center is solid, my upper body feels light. I breathe deeply, and I feel expanding, energy passing through my body till I feel my body boundary expanding, dissolving. For a moment, I become part of the whole environment, in a state of unity with something larger, sensing spiritual embodiment. A tear of compassion then in my eyes: I am deeply aware of the pain and the grief around the world, so many losses, yet some comfort coming from becoming part of "body-nature." I am reminded of life cycles and how we can recreate strength and resilience by fully living the related emotions with consciousness, in contact with our creative self, embedded in nature.

Donatella Mondino: When I woke up on the first morning of the Italian lockdown in March 2020, I was struck by the absence of human sounds: no background of distant traffic, no voices from joggers, runners, or passersby. After a few hours, in that greatest silence when even the birds fell silent, I found myself listening to the wind that around lunchtime descends from the mountains toward the plain, and I slowly realized that the rhythm of my breathing was changing. As I opened my shoulders and sank my feet into the earth, my arms and hands swayed a little, like little twigs. Every day, that encounter with the wind connected me with the energy of life that continued to visibly flow around and within me. Every day, feeling like a tree, has nourished my roots, making me more stable and developing my flexible branches, making me more capable of accommodating the unexpected.

Mimma Della Cagnoletta: Looking at a tree and painting is my way of meditating and taking in that part of nature that I feel I am. It's a process with no words attached. The tree that comes out of my drawing is never the tree that I have been looking at. It's a meeting of inner and outer dimensions that strengthen my bond with life (Figure 5). 


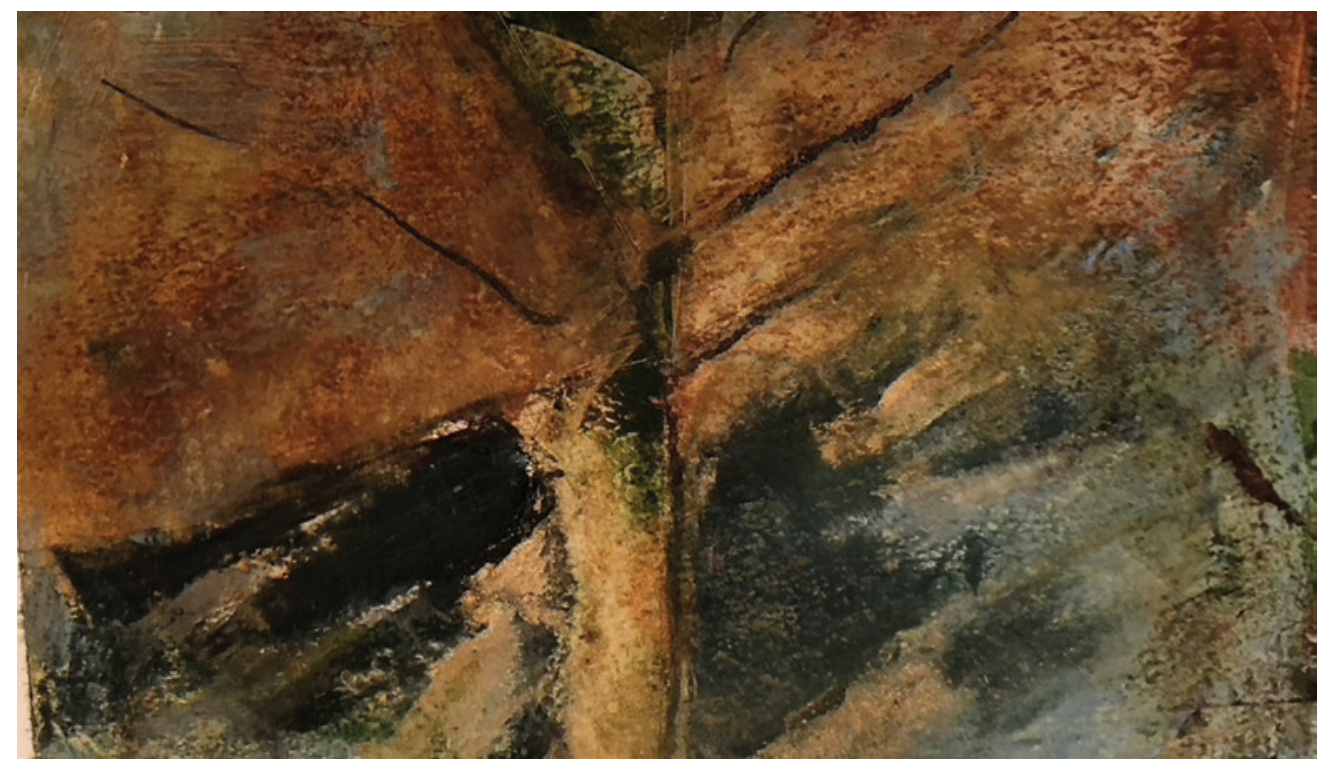

FIGURE 5 | Res Naturae: in my dream (Nia 2021).

\section{About the Authors}

Mimma Della Cagnoletta, is a certified psychologist, art therapist, and psychoanalyst and painter. She is a co-founder of Art Therapy Italiana (1982). She has been teaching and supervising for three decades and was a former professor at the University of Milan. She is now the director of advanced studies in art therapy for Art Therapy Italiana. She runs art therapy groups for users and professionals in many health services and private institutions. She works with dance movement therapists in order to integrate art and movement into teaching and practice. She is in private practice in Milan, working with adults. She is an author of an art therapy handbook and a co-author of a book on group art therapy as well as many articles. She is a member of the editorial board of CAET, a member of the European Federation of Art Therapy, and an honorary member of the Italian Professional Association of Art Therapists.

Rosa Maria Govoni, DMT, BC-DMT, is a psychologist, psychotherapist, dance movement therapy teacher, clinical supervisor, Authentic Movement trainer, sensorimotor psychotherapist level 1, introductory level KMP, restorative psychotherapy (Gray), co-founder of the Art Therapy Italiana, former director of the DMT Training Program and co-director of the Institute Expressive Psychotherapy. She is also the director of continuing education in DMT-Art Therapy Italiana, a faculty member of the Circle of Four. She worked as a dance movement psychotherapist in public and private institutions and is now in private practice. She is a o-founder of the Italian National Association of DMT (APID). She taught in Austria, Germany, Turkey (Bilgi University), Russia, Switzerland, and China (Inspirees). She has published articles related to dance movement psychotherapy, education, and supervision in Italian, 
English, and Russian. She is on the editorial board of the magazine Body Movement and Dance in Psychotherapy published by Routledge. E-mail: r.m.govoni@sunrise.ch.

Donatella Mondino is an art therapist, supervisor, and teacher at Art Therapy Italiana's Training Program. She is a founding member and executive manager of Art Therapy Italiana and founding member and former president of the Italian Professional Association of Art Therapists. She is a co-author of Arte Terapia nei gruppi, with Mimma Della Cagnoletta and Isabella Bolech. In the last ten years, she has studied Eastern philosophies, Taoism, and Confucianism and how they influence the arts.

\section{References}

Adler, J. (1999). Who is the witness. In P. Pallaro (Ed.). Authentic movement: Essays by Mary Stark Whitehouse, Janet Adler and Joan Chodorow (pp. 141-159). London \& Philadelphia: Jessica Kingsley.

Adler, J. (2002). Offering from the conscious body. Rochester, VT: Inner Traditions.

Bartenieff, I., with Lewis, D. (1980). Body movement, coping with the environment. London, UK: Gordon \& Breach.

Bernstein, P. L. (1979). Eight theoretical approaches in DMT. Dubuque, IA: Kendall Hunt.

Damasio, A. (2018). The strange orders of things. New York: Knopf Doubleday Publishing Group.

Della Cagnoletta, M. (2010). Arte terapia, la prospettiva psicodinamica. Rome: Carrocci Ed.

Govoni, R. M., \& Weatherhogg, A. P. (2007). The body as theatre of passions and conflicts; affects, emotions and defenses. Body, Movement and Dance in Psychotherapy, 2(2), 109-121.

Gray, A. E. L. (2017). Polyvagal-informed dance movement therapy for trauma: a global perspective. American Journal of Dance Therapy, 39, 43-46.

Halprin, A. (1997). Dance as a healing art. San Rafael, CA: Tamalpa Institute.

Hillman, J. (1977). Re-visioning Psychology. New York: HarperCollins.

Kestenberg, A. J., Loman, S., Lewis, P., \& Sossin, K. (1999). The meaning of movement. London, UK: Gordon \& Breach.

Laban, R. (1960). The mastery of movement. London: Donald \& Evans.

Milner, M. (1987). The supreme madness of sane men. London: Tavistock.

Ogden, P., Minton, K., \& Pain, C. (2006). Trauma and the body. New York: W. W. Norton.

Payne, H. (2021). Authentic movement and the development of the ecological self [webinar]. IACAET Events, IACAETOrg.

Plevin, M. (2007). The movement of all things: Authentic Movement and quantum physics. In P. Pallaro (Ed.), Authentic Movement, volume 2 (pp. 55). London \& Philadelphia: Jessica Kingsley.

Porges, S. W. (2011). The polyvagal theory neurophysiological foundations of emotions, attachment, communication and self-regulations. New York: W. W. Norton.

Sacks, O. (2019). Everything in its place: first loves and last tales. Toronto, Canada: A. Knopf.

Serlin, I. A. (2020). Dance movement therapy: Whole person approach to working with trauma and building resilience. American Journal of Dance Therapy, 42, 176-193.

Stromsted, T. (1998). Re-inhabiting the body. In D. H. Johnson \& I. J. Grand (Eds.), The body in psychotherapy (pp. 147-169). Berkeley, CA: North Atlantic Books.

Whitehouse, M. (1979). C. G. Jung and dance therapy. In P. L. Bernstein (Ed.), Eight theoretical approaches in dance movement therapy (pp. 51-70). Dubuque, IA. Kendall Hunt.

Winnicott, D. W. (1971). Playing and reality. London: Penguin Books.

Winnicott, D. W. (1988). Human nature. London: Free Association Books. 